\title{
Interpersonal Communication Predispositions for Lifelong Learning: The Case of First Year Students
}

\begin{tabular}{ccc}
\hline Article Type & Received Date & Accepted Date \\
Research & 28.10 .2017 & 07.08 .2018 \\
\hline
\end{tabular}

\section{Tanju Deveci*}

\begin{abstract}
The idea that learning continues throughout life, and cannot be confined to a particular age or place is a fact. This has led to the argument that individuals need to be active agents of their own learning. This has caused learning to be viewed as an individual attainment, with little attention to the role of interpersonal communication in advancing lifelong learning skills. With an attempt to bridge this gap, this paper focused on 205 college students' and five professors' thoughts on the interplay between our communication with others and lifelong learning. Considering their views as well as literature on interpersonal communication and lifelong learning, a thirty-item scale with four sub-domains was developed: learning reciprocity, perseverance, engagement with instructors, and motivation. This scale was then used with a total of ninety-two of first year students on two communication courses in the UAE. Results revealed that the students' scores were above average, indicating their relatively developed predispositions for interpersonal communication supporting lifelong learning. The project-based nature of the courses the students were registered in was thought to influence students' scores. Results are discussed, and recommendations are made for both classroom instruction and future research.
\end{abstract}

Keywords: Interpersonal communication, lifelong learning, first year students, project-based learning.

\footnotetext{
* Assistant Professor, Khalifa University of Science and Techonology, The College of Arts and Sciences, Department of English, Abu Dhabi, The UAE. E-mail: tanjudeveci@yahoo.com, https://orcid.org/ 0000-0001-5905-9793
} 


\title{
Yaşam Boyu Öğrenme için Kişilerarası İletişim Eğilimleri: Birinci Sınıf Öğrencileri Örneği
}

\begin{tabular}{ccc}
\hline Makale Türü & Başvuru Tarihi & Kabul Tarihi \\
Araştırma & 28.10 .2017 & 07.08 .2018 \\
\hline
\end{tabular}

\section{Tanju Deveci}

\begin{abstract}
$\ddot{O} z$
Öğrenme yaşam boyu sürer ve belirli bir yaş ile sınırlandırılamaz. Bu durum bireylerin öğrenme süreçlerinde aktif bir rol üstlenmesi gerektiğine yönelik görüşlerin ağırlık kazanmasına neden olmuştur. Ancak bu görüş aynı zamanda, öğrenmenin temel olarak bireysel bir girişim olduğu düşüncesine yol açmıştır. Yaşam boyu öğrenme becerilerinin geliştirilmesinde kişilerarası iletişimin rolüne yeterince ilgi gösterilmemiştir. Bu araştırma yaşam boyu öğrenme ve diğer insanlarla iletişimimiz arasındaki ilişkinin doğasını belirlemek üzere yürütülmüştür. Bu amaçla ilgili alanyazın incelenmiş, 205 üniversite öğrencisi ve beş öğretim görevlisinin görüşleri alınarak 30 maddelik bir ölçek geliştirilmiştir. Bu ölçek 'karşılıklı öğrenme', 'sebatkarlık', 'eğitmenlerle etkileşim' ve 'güdülenme' olarak isimlendirilmiş dört alt alandan oluşmuştur. Geliştirilmiş olan ölçek Birleşik Arap Emirlikleri’ndeki bir üniversitede iletişim dersleri alan 92 birinci sınıf öğrencisine uygulanmıştır. Sonuçlar öğrenci puanlarının ortalamanın biraz üzerinde olduğunu göstermiştir. $\mathrm{Bu}$ sonuç öğrencilerin yaşam boyu öğrenmelerini destekleyeci türden kişilerarası iletişim eğilimlerinin nispeten gelişmiş olduğuna işaret etmektedir. Öğrencilerin aldıkları iletişim dersinin proje-temelli doğası bunun temel nedeni olarak değerlendirilmektedir. Sonuçlar tartışılmakta ve gerek eğitim gerekse gelecekteki araştırmalara yönelik önerilerde bulunulmaktadır.
\end{abstract}

Anahtar Sözcükler: Kişilerarası iletişim, yaşam boyu öğrenme, birinci sınıf öğrencileri, projetemelli ögrrenme. 


\section{Introduction}

Defined as "the development of human potential through a continuously supportive process which stimulates and empowers individuals to acquire all the knowledge, values, skills, and understanding they will require throughout their lifetimes and to apply them with confidence, creativity, and enjoyment in all roles, circumstances, and environments" (Longworth \& Davies, 2013, p. 22), lifelong learning (LLL) has now become the guiding principle for many education planners, practitioners, and learners. LLL puts individual members of society at the center of attention. To help them meet various needs, individuals are provided with continuous support in the form of specially trained professionals, a welcoming and sympathetic attitude, and an appropriate learning infrastructure (Longworth \& Davies, 2013). Its aim is to "provide people of all ages with equal and open access to high-quality learning opportunities and to a variety of learning experiences" both "inside and outside formal education and training systems" (OECD, 2004, p. 126).

The emphasis on the individual learner indicates that "it is the individual who makes the decision, the individual who will make the effort, and the individual who will benefit from the learning process" (Longworth \& Davies, 2013, p. 23). Although this view underscores the role of learner-centered approach, it may overlook the social nature of learning that points to communication dynamics playing a significant role in the manifestation of learning needs and how these needs are addressed through interaction with others. A "learner-centered approach" devoid of adequate attention to interpersonal aspects of the learning process may result in the individuals' "alienation within the learning environment from other learners and the reproduction of the alienated relationships within the wider social formation," and "[t]he practices ... developed to meet the needs of individuals reinforce the identity of persons as separate from one another" (Edwards, 2001, p. 43). To reduce any likelihood of this, the social context in which the individual learner is situated needs to be taken into consideration with a view towards individuals having an effect on each other's aptitude for lifelong learning.

Despite the spate of interest in learner-centered approaches in lifelong learning, it seems that there is a lack of literature on the role of interpersonal communication in promoting lifelong learning. To this end, this research aims to identify individuals' attitudes towards interpersonal communication in the learning and teaching environment as a key indicator of current and future engagement in lifelong learning. It is essential to understand how a person's engagement in interpersonal communication affects his/her success in lifelong learning. It is also important to identify the ways in which individuals' learning and communication orientations affect others' lifelong learning experiences. Considering this, the impetus for this research comes from a philosophical view of social interaction defined as "the process whereby the overt movements, covert deliberations, and basic physiology of one individual influences those of others, and vice versa" (Turner, 1988, p. 13), and the social constructivist view of learning that "the locus of knowledge [resides not] in the individual but in socially constructed products yielded through the interaction of individuals in their social context" (Devos, 2016, p. 48).

\section{Research Questions}

With the importance placed on interpersonal relationships for lifelong learning, in this research I aimed to answer the following questions.

1) What is the level of first year students' interpersonal communication predispositions for lifelong learning?

2) Does gender play a role in their interpersonal communication predispositions for lifelong learning scores?

3) Do the courses students take play a role in their interpersonal communication predispositions for lifelong learning scores? 


\section{Literature Review}

\section{Lifelong Learning}

There are a variety of definitions of lifelong learning; one of which is given above. The definitions are influenced by the philosophical approach adopted. From the existential perspective, Jarvis (2009) defines it as "the process of transforming experience into knowledge and skills, etc., resulting in a changed person-one who has grown and developed as a result of the learning" (p. 11). This definition, according to Jarvis, suggests that learning is essential for the growth and development of a person who is functioning as a useful member of society.

Titmus (1989, p. 548) states the concept of lifelong learning derives;

... from the concept that education is not a once-for-all experience that is confined to an initial cycle of continuous education commenced in childhood, but a process that should continue throughout life. Life itself is a continuous learning process, but each person needs specific opportunities for continuing, purposive and sequential learning in order that he or she may keep abreast of technical and social change, may equip himself or herself for changes in his or her own circumstances...

Although the term "lifelong learning" has become a catchphrase in European initiatives over the last half a century, its foundations can be found in much earlier times. Gelpi (cited in Matheson \& Matheson, 1996, p. 220) warns that "the concept and practice of lifelong learning belongs to the world history of education and cannot be confined only to the culture of one country or a single period of history." Philosophers like Socrates, Plato, and Aristotle, who underscored the importance of cultivating intellectually advanced individuals through efficient use and training of the mind, argued that learning spans our life cycle (Lewis, 1981). On the other hand, Confucius pointed to the significance of such an approach to learning by saying that "[L]ife is limited, while learning is limitless" (Guo-Dong, 1994, p. 272).

In line with Jarvis's definition above, the early foundations of the term emphasized the humanistic approach to learning which underscores the role of learning and education in enhancing personal growth and development, facilitating self-actualization, and supporting the development of those that are open to change and continued learning (Kumar, 2012). However, it is argued that the notion of lifelong learning and lifelong education, in a world that is often defined in economic terms, differs greatly from that of its early supporters (Matheson \& Matheson, 1996). The heavy emphasis put on the regulation of employment by organizations such as the World Bank and the Organisation for Economic Co-operation and Development (OECD) encourages individuals and organizations to approach lifelong learning from purely economic perspectives at the expense of personal fulfillment and democratic empowerment (Sayılan, 2015; Edwards \& Stimpson, 2003).

Lifelong learning requires learners to acquire certain skills. Approaching the topic from the perspective of information literacy, Gilton (2012) states that "lifelong learners can informally educate themselves through self-teaching or consulting with experts, take advantage of institutions promoting formal learning, ... or pursue more formal education" (p.67). Similarly, Duman (2007) sees "knowledge literacy" as a prerequisite for lifelong learning. He states that people with knowledge literacy skills know what knowledge they need and how they can obtain it. They also evaluate the usefulness and accuracy of sources and organize different kinds of information in order to use it purposefully.

For university students to pursue learning as a lifelong endeavor, they are expected to exhibit the following abilities (Dunne, 1999, p. 131):

a) setting realistic and personally meaningful learning goals,

b) identifying and using appropriate resources to help them achieve their goals,

c) having well-developed reading, writing and study strategies,

d) having effective information retrieval and selection skills, 
e) using computer and information technology appropriately,

f) plan and monitor learning and adapt strategies if needed,

g) reflecting on and evaluating the outcomes of learning, and

h) recognizing and dealing effectively with obstacles to learning.

On the other hand, Jarvinen (1998) draws attention to the role of lifelong learning inside the workplace and specifies "high-level communication," "team learning," "network learning," "perspective sharing," "knowledge conversion," and "reflective practice" as among key lifelong skills.

\section{Interpersonal Communication}

Sarvaiya (2013) notes that humans have both biological and social needs to live in a society where they communicate with others. He points out that the former stems from the necessity of addressing needs like food, safety, and sex which require social cooperation. The latter, on the other hand, is related to our mental growth and psychological need for belongingness, which is only possible through communication with others. This deep-seated need to communicate with others helps with the development of self and contributes to the value of our existence (Hargie, 2016). Together, these point to the role of communication with others, i.e. interpersonal communication, throughout our lives. A simple definition of interpersonal communication is "communication that occurs between people and creates a bond between them" (Solomon \& Theiss, 2013, p. 5). This highlights the importance of how it connects people. It also gives an indication of how our actions affect and reflect others' actions and how personal qualities influence interaction dynamics (Solomon \& Theiss, 2013). This also shows that interpersonal communication is not simply information transmission between people, but rather the way in which meanings, identity, and relationships are created and negotiated through social interaction (Braithwaite, Schrodt \& Carr, 2015).

There are a variety of skills one needs to acquire in order to be a skillful interpersonal communicator. One of these is the skill of self-awareness, which can be defined as "the extent to which [people] accurately know [themselves]" (Alusine \& Kanu, 2011, p. 66). It involves awareness and acceptance of our thoughts, beliefs, biases, prejudices, behaviours, and values (Berman, Kozier \& Erb, 2015). Those who are not aware of their feelings and reactions cannot communicate them to another person, and those who do not accept their feelings and reactions will try to hide them (Johnson, 1978), which reduces the quality of their interpersonal communication. On the other hand, awareness and acceptance of them will help reinforce positive feelings and thoughts and mitigate negative ones. This will also help one to empathize with others. Self-awareness is facilitated by reflective thinking, which is defined by Dewey (1933) as "the kind of thinking that consists in turning a subject over in the mind and giving it serious and consecutive consideration" (p. 3). Individuals that are engaged in introspection through reflective thinking become aware of their own as well as others' thoughts, feelings, and beliefs and how these are influenced by their experiences. Reflective thinking encourages people to use higher-order thinking skills and facilitates self-directed learning (Lewittes, 2009).

Effective listening, also known as active listening, is the third interpersonal communication skill. Williams (n.d.) defines effective listening as "actively absorbing the information given to you by a speaker, showing that you are listening and interested, and providing feedback to the speaker so that he or she knows the message was received" (para. 5). Williams also notes that effective listening requires choosing the right words and nonverbal cues when conveying a message so that those involved in communication will interpret it in the way intended. The common understanding created thanks to effective listening motivates both parties and reduces the likelihood of conflicts.

Nonverbal communication is another skill required for effective interpersonal communication. It is estimated that $93 \%$ of all meaning is nonverbal (Burgoon, Guerrero \& Floyd, 2016). This makes the role of nonverbal communication evident in interpersonal communication. Anderson (2009) identifies a variety of ways in which nonverbal communication can be channeled. One of these is "physical appearance," which includes body type, clothing style, age, height, etc., that create impressions and determine how relationships develop. Another one is "kinesics." This is related to facial expressions, 
posture, gestures, and interactional synchrony, the effective use of which facilitates interpersonal communication. "Oculesics," on the other hand, is related to eye contact, which determines the degree to which the listener is involved in the conversation.

Interpersonal communication predispositions have a vital role to play in educational settings. There is empirical evidence indicating that students' academic self-perceptions, school engagement, motivation, and performance are positively correlated with the quality of relationships with their teachers and peers (Furrer, Skinner \& Pitzer, 2014). A positive interpersonal relationship between a teacher and student has a favorable effect on a student's academic and non-academic adaptation to school (Martin \& Collie, 2016). First year students' well-being has also been identified to be positively affected by the relationship students established through extracurricular activities organized to develop their interpersonal skills by expanding their circle of friends and ways of interaction with faculty (Deveci \& Nader, 2017).

On the other hand, effective listening as "the primary channel of instruction at all levels" (Duck \& McMahan, 2017), will undoubtedly increase students' understanding of the subject matter. It is also a key factor in developing relationships between students and their instructors and between students and their academic advisors (Duck \& McMahan, 2017). Students also need to display social skills to effectively work and cooperate with each other. Attentive listening as a social skill enables them to understand each other's points of view, feelings, and needs (Canter, 2006). Skillful users of nonverbal communication, on the other hand, are better at initiating, developing, and maintaining positive relationships with their classmates as well as their teachers (Davis, 2001). Taken together, these point to the role of interpersonal communication tendencies in determining students' academic success and overall well-being.

\section{Role of Interpersonal Communication in Lifelong Learning}

Although the need for interpersonal communication is innate, interpersonal communication skills are acquired and can be enhanced throughout life. In our technology-rich world where constant interaction with people from different backgrounds and cultures has become the norm, this requires a lifelong learning approach to interpersonal communication. Therefore, interpersonal communication and lifelong learning cannot be divorced from each other. That is, interpersonal communication plays multiple roles in facilitating lifelong learning endeavors, which also causes lifelong learners to communicate interpersonally. In the workplace, for instance, there is now more empirical evidence that interpersonal relationships with co-workers and supervisors ease individuals' efforts to keep themselves up-to-date (Head, 2016). In school contexts, students' lifelong learning skills at metacognitive level are supported through the use of peer reviews. Students are able to evaluate, monitor, and improve their own work more successfully when they engage in effective analysis of their peers' work and give them feedback (Ambrose, Bridges, Dipetro, Lovett \& Norman, 2010). In this way, the unique life experience of each student in the classroom becomes a learning source from which their peers can benefit. Such a student-centered approach to learning avoids instructor-controlled expositions in favor of active learning and allows for individual and team-based activities that incorporate meaningful and relevant, open-ended problems through which students can create, acquire, and connect (Brandt \& Dimmitt, 2015). It also allows for active learning opportunities, which help build positive teacher-student relationships, facilitating instructors' attempts to introduce forms of teaching and learning that involve active student participation (Kember \& Leung, 2005). Active learning also involves students in learning activities built around communication with others. This gives them the chance to practice a variety of interpersonal communication skills. One of these is the skill of conflict resolution, which they use to persevere in the face of challenges. That is, students need to learn how to best tackle issues that appear when working with others, channeling their energy toward positive outcomes. Successful results will undoubtedly increase everyone's self-confidence and improve relationships in the learning context. Taken together, they will play a positive role in making learning meaningful and long-lasting as well as contribute to the individuals' development of lifelong learning skills. 
The role of interpersonal communication is also evident in official documents prepared by international organizations. One of these is the European Commission that identified eight "key competences" in their reference framework for lifelong learning in 2005.

The first competence, communication in the mother tongue, points to the significance of interpersonal communication by noting that individuals need to be able to "interact linguistically in an appropriate way in the full range of societal and cultural contexts - education and training, work, home, and leisure," for which they need to acquire the skill of "communicat[ing] in oral and written forms in a variety of communicative situations and to monitor and adapt their own communication to the requirements of the situation," and "a positive attitude towards... interaction with others" (p. 13). On the other hand, the second competence is related to communication in foreign languages and involves "sharing the main skill dimensions of communication in the mother tongue: it is based on the ability to understand, express and interpret thoughts, feelings, and facts in both oral and written form (listening, speaking, reading, and writing) in an appropriate range of societal contexts - work, home, leisure, education, and training - according to one's wants or needs" (p. 3).

The third competence is related to science and technology and requires individuals to acquire and apply knowledge and methodology to address society's needs, in which they need to act as responsible citizens. The fourth competence concerns digital competence, which is related to interpersonal communication through the use of an individual's skills in communicating and participating in collaborative networks via the Internet.

On the other hand, the fifth competence of learning to learn underscores the importance of interpersonal communication skills since individuals are expected to "organize their own learning ... through effective management of time and information, both individually and in groups," which requires them to "share what they have learnt ... and to seek advice, information, and support when appropriate" (p. 15). This is a corollary to the sixth competence related to interpersonal, intercultural, and social competences that "cover all forms of behaviour that equip individuals to participate in an effective and constructive way in social and working life, and particularly in increasingly diverse societies, and to resolve conflict where necessary" (p. 16). For this to happen, people as lifelong learners need to raise their awareness of the codes of conduct and manners in different contexts. They also need to engage in constructive communication, understand different perspectives, and negotiate effectively through use of empathy.

The sixth competence, entrepreneurship, also points to the role of interpersonal communication by identifying essential project management skills that include communicating, de-briefing, and working collaboratively in teams. Finally, the last competence, cultural expression, highlights the significance of being able to "relate one's own creative and expressive points of views to the opinions of others" (p. 18).

Collectively, it is evident that none of the competences acts in isolation from each other: they are interdependent and support individuals' efforts to become lifelong learners. It is also important to note that knowledge of these competences per se is not sufficient for learning to be meaningful. They need to be put into practice at both individual and interpersonal levels. Considering the social nature of humans, it is essential that individuals relate to others in their pursuit of engaging in learning activities throughout their lives.

\section{My Research Context: Lifelong Learning and Interpersonal Communication in Engineering}

This research was conducted in the context of the Petroleum Institute (PI) ${ }^{1}$ in Abu Dhabi, which is a university offering degrees in various engineering disciplines such as Petroleum Geosciences, Electrical Engineering, and Mechanical Engineering. Accredited by the Accreditation Board for Engineering and Technology (ABET), the university aims to instill lifelong learning skills in its students. The third ABET criterion entails that engineering students have "recognition of the need for and an ability to engage in lifelong learning" (2014, p. 3). Considering the pace at which technology

\footnotetext{
1 PI has recently been merged with two other higher education institutions. The name of the new university is Khalifa University of Science and Technology (KUST).
} 
advances and its effects on engineering students' employability after graduation (Deveci, 2014), the significance of this criterion becomes self-evident. It is important for practicing engineers to "learn to treat their professional skills as a dynamic project that needs continuous upkeep and upgrading" (DiDomenico, 2010). To help achieve this, Bowman (1997) suggests that individual engineers should have a lifelong learning plan reflecting their career aspirations. They should regularly update their plans and engage in interpersonal communication with their employers and colleagues about their plans. He also suggests that educational institutions should establish lifelong learning programs that include courses specifically designed for engineers that graduated ten or more years ago or for those planning career changes.

ABET's third criterion states that engineering students need to have "an ability to communicate effectively" and to "function on multidisciplinary teams" (2014, p. 3), both of which point to the significance of interpersonal communication skills in engineering disciplines. In addition to written communication skills related to technical reports, feasibility studies, and emails, engineers need to be efficient users of oral communication skills which are necessary for face-to-face communication, telephone usage, formal presentations (Tenopir \& King, 2004), as well as digital communication venues such as social media (Patil \& Eijman, 2012). They also need to have entrepreneurial skills that help them interact with and operate business ventures (Riemer, 2007), which is identified as one of the essential competences for lifelong learning by the European Council (2005).

It has also been noted that engineers in various disciplines such as Materials Design may face cross-category issues that would only be possible to solve through collaboration with engineers in other disciplines (Özturk, Deveci, Günister \& Simmons, 2015). Although communication skills like negotiating will be useful in these situations, engineers from different disciplines working on the same project need to be able to "function on multidisciplinary teams" (ABET, 2014). For this to happen, team members need to be open to sharing roles and responsibilities, trust in each other's competencies, and be tolerant and accepting of different perspectives (Roncaglia, 2016). As such, "the success... does not just depend on good designs and architectures, bu[t] also on the socialization of team members across each project/design and interactions between team and team members to communicate lessons learned" (Crowder, Carbone \& Demijohn, 2016, p. 31).

\section{Method}

There were two phases of data collection for this study. The first phase included the development of the data collection tool, while the second phase included a small-scale study in which the instrument was used to determine the students' level of interpersonal communication predispositions for lifelong learning. Hence, this section is divided into two subsections describing each stage in detail.

\section{Phase 1: Development of the Data Collection Tool}

To collect data for the purposes of this study, I developed the Scale of Interpersonal Communication Predispositions for Lifelong Learning (SICP-LLL). This took several stages. First I reviewed the literature on both interpersonal communication and lifelong learning. In doing so, I paid close attention to earlier research that investigated lifelong learning skills (e.g. Erdoğan \& Arsal, 2016; Coşkun \& Demirel, 2012; Uzunboylu \& Hürsen, 2011), and research that investigated interpersonal communication skills (e.g. Korkut-Owen \& Bugay, 2014; Bienvenue, 1971). This helped me identify the themes relating to the use of interpersonal communication predispositions for lifelong learning. The accuracy of the themes was checked with two other specialists in the field of lifelong learning and three other scholars specialized in communication studies. The same team of specialists reviewed the pool of 40 statements reflecting the sub-themes for content validity. Out of this number, a total of 35 items were unanimously agreed upon and included in the initial scale. During the pilot study of the scale with a group of 40 students, the number of items was reduced to 30. I also adjusted the wording of certain statements for students' ease of comprehension. (See Appendix).

This new version of the scale was administered to 205 randomly chosen students, comprised of $25(12 \%)$ foundation students, $158(77 \%)$ undergraduate students, and $22(11 \%)$ graduate students. Exploratory factor analysis and was conducted using the SPSSS 20 packet program. The students' 
ages varied between 17 and 42, with a mean age of 20. While $76(37 \%)$ of them were male, $129(63 \%)$ of them were female.

In analyzing the data from the above-mentioned student population, I used the rotation method Oblimin with Kaiser Normalization. I also conducted Kaiser-Meyer-Olkin (KMO) and Barlett's test of sphericity (BTS). A KMO value of $.812>.60$ together with a BTS value of $1511.29(\mathrm{df}=435, \mathrm{p}=.000)$ indicated that SICP -LLL was suitable for factor analysis. A KMO value above .5 has been established to be acceptable (Kaiser, 1974). Using the data set, I extracted a fixed number of four factors in accordance with the themes identified during the literature review phase. I excluded the factors with low loading (.30 or less), and the factor loading resulted in a total number of 30 items (Learning reciprocity $=12$; Perseverance=7; Engagement with instructors=5; Motivation=6). Item 15 ("I don't give up easily in the face of a learning problem caused by other people") loaded on both factor 1 and factor 2 (.491 and .302). However, considering the literature on an individual's persistence in pursuing their learning goals when they are faced with difficulties (Deveci, 2013; Coşkun \& Demirel, 2012; Rovai, 2003), I decied that this item should be retained under the second factor perseverance "with the assumption that it is the latent nature of the variable" (Yong \& Pearce, 2013, p. 84). Also, the Cronbach Alpha for the whole scale was found to be .85 , and it was .78 for learning reciprocity, .74 for perseverance, .72 for engagement with instructors, and .70 for motivation. Taken together, these indicate that SICP -LLL is a reliable instrument.

The SICP-LLL uses a 5-point Likert-type scale with responses to items ranging from 5, "completely agree," to 1 , "completely disagree." Some statements are negatively worded, requiring reverse scoring. The highest, the lowest, and the average scores that can be attained for the whole scale as well as the subscales can be seen in Table 1.

\section{Table 1}

SICP - LLL Score Range

\begin{tabular}{lcccc}
\hline & N & Min & Max & $\overline{\mathrm{x}}$ \\
\hline Engagement with instructors & 5 & 5 & 25 & 12.5 \\
Motivation & 6 & 6 & 30 & 15 \\
Perseverance & 7 & 7 & 35 & 17.5 \\
Learning reciprocity & 12 & 12 & 60 & 30 \\
Scale as a whole & 30 & 30 & 150 & 75 \\
\hline
\end{tabular}

\section{Phase 2: Use of SICP-LLL}

I used the newly developed SICP-LLL to determine first year students' interpersonal communication predispositions for lifelong learning in the context of the Communication Department at PI. A total of 92 students participated in this phase of the study. The sampling technique was based on the convenience model. Of the students, 27 (29\%) were male, and $65(71 \%)$ were female. Their ages ranged from 17 to 23, with a mean age of 19 .

Twenty-seven (29\%) were from COMM101, and 65 (71\%) were from COMM151. Both courses are based on Project-based Learning (PbL). The former is a prerequisite for the latter, and it teaches students the fundamental language and communication skills that are required for successful undergraduate study. Students are assigned project topics related to various communication theories as well as other skill areas such as time-management skills and healthy student life. The latter, on the other hand, builds on knowledge and skills learned in COMM101, and teaches students more advanced academic literacy skills through their engagement in projects centered upon technical topics of general interest. These include topics such as energy consumption, and campus design.

The Cronbach Alpha computed for the scale was found to be .80. Student's t-test was used to determine the statistical significance level when comparing the data sets according to gender and course variables. A p-value of lower than .05 was considered statistically significant. 


\section{Results}

The first research question aimed to identify first year students' interpersonal communication predispositions for lifelong learning, while the second one concerned the effect of gender on students' scores. The results of the data analysis for these questions can be seen in Table 2 .

Table 2

Students' SICP-LLL Scores

\begin{tabular}{|c|c|c|c|c|c|c|c|c|c|c|c|c|c|c|}
\hline & \multicolumn{3}{|c|}{$\begin{array}{l}\text { Student scores } \\
\quad \mathrm{N}=92\end{array}$} & \multirow[b]{2}{*}{$\begin{array}{l}\mathrm{S} \\
\mathrm{D}\end{array}$} & \multicolumn{4}{|c|}{$\begin{array}{c}\text { Male } \\
\text { participants' scores } \\
\mathrm{N}=27\end{array}$} & \multicolumn{4}{|c|}{$\begin{array}{c}\text { Female participants' } \\
\text { scores } \\
\mathrm{N}=65\end{array}$} & \multirow[b]{2}{*}{$\mathrm{t}$} & \multirow[b]{2}{*}{$\mathrm{p}$} \\
\hline & $\begin{array}{c}\mathrm{Mi} \\
\mathrm{n}\end{array}$ & $\begin{array}{c}\mathrm{Ma} \\
\mathrm{x}\end{array}$ & $\overline{\mathrm{x}}$ & & $\begin{array}{c}\mathrm{Mi} \\
\mathrm{n}\end{array}$ & $\begin{array}{c}\mathrm{Ma} \\
\mathrm{x}\end{array}$ & $\overline{\mathrm{x}}$ & $\begin{array}{l}S \\
D\end{array}$ & $\begin{array}{c}\mathrm{Mi} \\
\mathrm{n}\end{array}$ & $\begin{array}{c}\mathrm{Ma} \\
\mathrm{x}\end{array}$ & $\overline{\mathrm{x}}$ & $\begin{array}{l}S \\
D\end{array}$ & & \\
\hline & 9 & 23 & 16 & & & & & & & & & & & \\
\hline $\begin{array}{l}\text { Engagement } \\
\text { with instructors }\end{array}$ & & & & 3 & 13 & 23 & 17 & 2 & 9 & 22 & 14 & 3 & $\begin{array}{c}.860 \\
9\end{array}$ & $\begin{array}{c}.195 \\
8\end{array}$ \\
\hline Motivation & 13 & 29 & 21 & 3 & 15 & 29 & 21 & 3 & 13 & 28 & 21 & 3 & $\begin{array}{c}.378 \\
6\end{array}$ & $\begin{array}{c}.352 \\
9\end{array}$ \\
\hline & & & & 3 & 19 & 32 & 26 & 4 & 15 & 32 & 25 & 3 & .901 & .184 \\
\hline Perseverance & 15 & 32 & 24 & & & & & & & & & & 4 & 2 \\
\hline $\begin{array}{l}\text { Learning } \\
\text { reciprocity }\end{array}$ & 31 & 57 & 44 & 5 & 37 & 57 & 46 & 6 & 31 & 57 & 46 & 5 & $\begin{array}{c}.166 \\
4\end{array}$ & $\begin{array}{c}.434 \\
1\end{array}$ \\
\hline Scale as a & & & 10 & 10 & 90 & 134 & 11 & 11 & 87 & 127 & 10 & 9 & - & .224 \\
\hline whole & 87 & 134 & 9 & & & & 0 & & & & 8 & & $\begin{array}{c}.761 \\
4\end{array}$ & 1 \\
\hline
\end{tabular}

As is seen in Table 2, the students' SICP-LLL scores varied between 87 and 134, with an average score of 109. This is above the mid-range of 75 computed for the scale, and therefore indicates students' moderate interpersonal communications predisposition for lifelong learning. The average score suggests that the students had some predispositions for interpersonal communication for lifelong learning. When the subscales are considered, it is seen that their average score was the highest for learning reciprocity, indicating that they valued the relationships of those whose assistance they can use to learn or of those they can assist in learning. It also suggests that they paid attention to other learners' communication styles when working together. They seemed to have an overall positive attitude towards learning interactions with others. The students' average scores for perseverance and motivation were also higher than the average score computed for the scale. Taken together, these indicate that the students were relatively strong in their aptitude for sustaining motivation and determination for learning when confronted with interpersonal challenges. They also seemed to be somewhat open to dialogue with their peers about their learning. On the other hand, their slightly above average score for engagement with instructors indicates that the students were likely to engage in conversation with their instructors about their learning without compulsion. They were likely to take the initiative to seek knowledge from their instructors in and outside of the classroom. This average score also indicates that they do see the rationale for the instructor's use of pair and groupwork activities that lend themselves to use of interpersonal communication skills for lifelong learning.

Table 2 also shows that the male students' overall average score was minimally higher than that of the female students (110 vs. 108); however, the difference was not at a statistically significant level $(\mathrm{p}=.2241>.05)$. When the subscales are considered, it is seen that the female and the male students received the same average score for learning reciprocity and motivation. This indicates that gender did not make a difference in terms of the students' skills of sharing and learning with their peers and their interest in working with others in their quest for making learning a lifelong endeavor. However, the male students' score for engagement with instructors was slightly higher than that of the female students (17 vs. 14). Their scores for perseverance, on the other hand, were almost the same (26 vs. 25). This data indicate that the male students might be slightly more skilled in their interaction with instructors on learning-related topics. However, the lack of statistically significant differences between the data sets indicate that these differences were only negligible. 
The third research question asked whether the students' scores were affected by the courses they took. The results are seen in Table 3 .

Table 3

Students' SICP-LLL Scores according to Courses

\begin{tabular}{|c|c|c|c|c|c|c|c|c|c|c|}
\hline \multirow[t]{2}{*}{ Subscales } & \multicolumn{3}{|c|}{$\begin{array}{c}\text { COMM101 } \\
\text { participants' scores } \\
\mathrm{N}=27\end{array}$} & \multirow[b]{2}{*}{$\mathrm{SD}$} & \multicolumn{4}{|c|}{$\begin{array}{c}\text { COMM151 participants' } \\
\text { scores } \\
\mathrm{N}=65\end{array}$} & \multirow[b]{2}{*}{$\mathrm{t}$} & \multirow[b]{2}{*}{$\mathrm{p}$} \\
\hline & Min & Max & $\overline{\mathrm{x}}$ & & Min & Max & $\overline{\mathrm{x}}$ & SD & & \\
\hline Engagement with instructors & 9 & 23 & 17 & 3 & 9 & 22 & 17 & 3 & -.5496 & .2919 \\
\hline Motivation & 17 & 29 & 21 & 3 & 13 & 28 & 21 & 3 & -.7885 & .2162 \\
\hline Perseverance & 19 & 31 & 25 & 4 & 15 & 32 & 25 & 3 & -.3487 & .3640 \\
\hline Learning reciprocity & 35 & 57 & 46 & 6 & 31 & 57 & 46 & 5 & .3483 & .3642 \\
\hline Scale as a whole & 91 & 134 & 109 & 11 & 87 & 127 & 108 & 10 & .3179 & .3756 \\
\hline
\end{tabular}

It is seen in Table 3 that the COMM101 students' SICP-LLL scores were minimally higher than that of the COMM151 students (109 vs. 108). However, the difference was not at a statistically significant level $(p=.3756>.05)$. Table 4 also shows that the average scores for the subscales were the same, further indicating that the type of course was not a factor affecting students' interpersonal communication predispositions for lifelong learning.

\section{Discussion}

My main motivation for this study came from the fact that interpersonal communication is an integral part of learning throughout life, making it an essential skill for individuals to be effective lifelong learners. This study identified four main interpersonal communication domains in which lifelong learning predispositions play a key role. One of these is "learning reciprocity," which includes lifelong learning skills such as displaying a genuine interest in engaging in a dialogue with others concerning learning as well as adapting communication styles according to other learners' characteristics and learning needs. These are particularly important for learning to continue through life. Being receptive to others' contributions to our learning is an important attribute. However, it is equally important to be willing to share with others and support their learning. The main reasons for this are the social nature of humans, who do not live in isolation from each other, and the fact that our learning is often shaped by our exposure to knowledge held by others. Interpersonal communication skills facilitate the process of acquiring information and knowledge and using them constructively at both individual and interpersonal levels. Enhanced relationships with others allow learners to become aware of both their own and others' identities and learning needs as well as learning strengths and weaknesses. This encourages them to take responsibility for each others' learning. It is also important to consider the fact that much of work life in our modern world is based on relationships with others, be it direct or indirect. Considering the observation that employees often consult their co-workers and supervisors in their efforts to keep themselves up-to-date with the ever-changing mandates of occupations (Head, 2016), the role of interpersonal communication skills in learning throughout life becomes more evident. All in all, these point to the interpersonal, intercultural, and social competences that assist "individuals [in] participat[ing] in an effective and constructive way in social and working life, and particularly in increasingly diverse societies" (the European Commission, 2005, p. 16).

The second interpersonal communication domain requiring lifelong learning skills is "perseverance." It includes a variety of skills such as maintaining motivation for learning in the face of challenges with others and aptitude for using different communication methods to acquire the information and knowledge that others have. Considering perseverance skills in relation to learners' communication with others is important since relationships with others can have a determining effect on one's learning aptitude, especially those who have not developed a strong self-efficacy. There is 
empirical evidence showing that positive feedback given to learners promotes positive selfperceptions (Burnett, 1999) while negative feedback reduces the chances of improving student behaviors (Weeden \& Winter, 1999). Nonetheless, learning experiences throughout life will put individuals in contact with others whose feedback cannot be manipulated. They will have both positive and negative feedback and work with difficult people. In fact, it may be themselves who create challenges for others. In either case, a successful lifelong learner needs to be aware of difficulties and tackle them successfully. This may require them to be mindful of their remarks on others' performances, or be tolerant towards the feedback they receive, and persevere in the face of challenges.

The third interpersonal communication domain identified in this study is related to learners' engagement with their instructors. "The length and quality of the education at schools assume a critical role for the ability and motivation which are targeted at prospective learning situations" which requires "[a] strategy of lifelong learning [during] school years" (Demirel, 2009, p. 1709). Students' interaction with their instructors during the school years have a serious impact on students' lifelong learning skills. Positive relationships established between instructors and students allow for active learning experiences (Kember \& Leung, 2005), requiring students to be efficient communicators. This current study has identified that the lifelong learning skills related to interaction with instructors include learners' initiatives to reach out for help and their interest in understanding instructional activities designed by the instructor. In this way, students that possess lifelong interpersonal communication skills increase their metacognition, and engage in dialogue with their instructors. This increases their understanding of content matter and helps them learn new ways of obtaining knowledge. Research shows that students' interaction with their instructors in their roles as an advisor contributes to students' sense of belonging to their institution and increases their problem-solving skills (Deveci \& Ayish, 2017).

The final interpersonal communication domain identified in order to determine lifelong learning skills is "motivation." It involves learners' enthusiasm for collaborating with others for learning purposes. Students with this attitude are also interested in learning about how others prefer to learn. This helps them learn about different learning styles and strategies. This is in line with previous research findings indicating that students interacting with each other learn from others, make connections more easily, consolidate new ideas, and view topics from multiple perspectives which increases their critical thinking skills (Hurst, Wallace \& Nixon, 2013).

Students' interest in how other students like to learn also allows them to adjust social learning experiences according to the preferences of others. This domain also includes students' motivation to have others' contributions when setting learning goals. Sharing goals with other learners not only increases motivation and accountability, but it also invites assistance from others (Reilly, 2008), which lends credence to the European Commission's (2005) lifelong learning competence of "seeking advice, information, and support when appropriate" (p. 15). Collectively, these skills allow students to generate intrinsic motivation for lifelong learning through relationships with others.

The results of this study related to first year students' interpersonal communication predispositions for lifelong learning are also important. The results showed that the students' average score was 109, with a 34-point difference from the mid-score (75) computed for the scale. Considering the fact that the students were only in their first year of college education, this could be a very promising result. The nature of the project-based courses in the Communication Department provides a strong indication of the reasons for the students' comparatively higher SICP-LLL scores. Both of the courses engage students in continuous teamwork activities, requiring them to use a variety of interpersonal communication skills. These courses' endorsement of independent learning supported by peers is highly likely to impact their SICP-LLL scores. This finding is supported by previous research which investigated the positive effects on interpersonal communication skills of experiential learning through group work (Skinner, Hyde, McPherson \& Simpson, 2016). Although this study did not deal with group work learning activities in the given experiential learning environment, it does point to the potential influence of enhanced interpersonal skills on students' lifelong learning propensities. The authors note that experiential learning experience with a focus on interpersonal communication sharpens students' analytical skills, and develops their ability to plan their work, and 
therefore increases students' confidence in their independent learning skills. Taken together, these will help them in acquiring the qualities of an efficient lifelong learner. In this way, students will become "better prepared ... in terms of self-improvement, critical thinking, and problem-handling" (Skinner et al., 2016, p. 26), which is of great importance when they face challenges in their work and daily lives at and beyond college.

The findings of this research related to the gender variable is also worth noting. The lack of a statistically significant difference between the male and female students suggests that they have a relatively similar aptitude for interpersonal communication for lifelong learning. In another study conducted on students' interpersonal communication propensities in the same institution, the male and female students were found to have similar average scores (Deveci \& Ayish, 2018). These findings are particularly important considering the university's plan to switch to co-education. At present, PI students have their education on gender-segregated campuses. However, as of the 2017-2018 academic year, the new intake will receive co-education, and the existing students will be given the option to choose between the two. The finding on students' SICP-LLL scores in this study may indicate a comparatively easier transition if the participants of this study opt for co-education. However, it is also important to note the finding that the male students had slightly higher scores than the female students for the subscale of engagement with instructors. One possible reason for this result may be related to the cultural orientations of the region in which this study was undertaken. That is, the Arab culture normally limits the interaction between males and females. If the female students in this study had male instructors at the time, they may have felt less comfortable in engaging in a dialogue with their instructors outside of class hours. This may have also had a negative impact on their incentive to contribute to class discussions and to ask the instructor questions. Previous research also showed that the male students in the UAE tended to initiate more interactions (Dukmak, 2010).

On the other hand, the lack of a significant difference between the COMM101 and COMM151 student scores is not surprising. The relatively brief time gap between the two courses within the same academic year may have prevented the occurrence of a significant difference. Also, the similar nature of these courses may have prevented COMM151 students from experiencing significantly more enriched learning environments enhancing their interpersonal communication predispositions for lifelong learning. However, their engagement in similar or richer learning experiences in their future university courses is likely to increase their SICP-LLL scores.

\section{Conclusion and Recommendations}

In this paper I argued that learning does not take place in isolation from others, but rather requires effective use of interpersonal communication skills. Also, the idea that learning is a lifelong endeavor necessitates special attention to the role of interpersonal communication in making learning efficient, meaningful, and long-lasting. The impetus for this study came from this observation, resulting in a scale developed to identify learners' orientations towards interpersonal communication for lifelong learning. Although it was challenging to identify the domains of such a scale due to the multiple facets of learning and interpersonal communication, literature on lifelong learning and communication together with university professors and students' introspection on the concepts provided four main domains: learning reciprocity, perseverance, engagement with instructors, and motivation. Even though these domains consist of specific skills, they should be seen as interdependent.

The results on first year students' interpersonal communication predispositions for lifelong learning indicated that their skills were above the threshold level. This suggests that given the opportunity, college students can indeed use and develop lifelong learning skills interpersonally. To further reinforce this, instructors may consider identifying and addressing students' learning styles based on social interaction. It is only natural that some students may be avoidant. Collaborative activities in the classroom may challenge such learners at first. However, with support they may be encouraged to interact with other learners and the instructor. This will help them become less dependent on the instructor and others, which is a lifelong learning skill in itself.

I conducted this research in the context of university education, affecting the domains identified for the scale developed. Other researchers may consider investigating student orientations in other 
contexts. For example, the characteristics of learners in adult education organizations or K-12 education may result in different and/or additional domains. Researchers may also investigate the development of interpersonal communication for lifelong learning longitudinally, aiming to identify factors at play. Another area of research is the association between the use of these skills and students' academic success.

\section{References}

ABET (2014, November). Criteria for accrediting engineering programs. Baltimore, MD: Engineering Accreditation Commission. Retrieved from http://www.abet.org/ uploadedFiles/Accreditation/Accreditation_Process/Accreditation_Documents/Current/eaccriteria-2012-2013.pdf

Alusine, M., \& Kanue, D. A. (2011). Experiencing interactive interpersonal communication. The USA: Xlibris.

Ambrose, S. A., Bridges, M. W., DiPietro, M., Lovett, M. C., \& Norman, M. K. (2010). How learning works: Seven research-based principles for smart teaching. San Francisco, CA: Jossey Bass.

Anderson, P. (2009). Nonverbal communication. In H. Reis \& S. Sprecher (Eds.). Encyclopedia of human relationships. New York: Sage Publication, Inc.

Bienvenue, M. J. (1971). An interpersonal communication inventory. Journal of Communication, 21(4), 381-388.

Berman, A., Kozier, B., \& Erb, G. L. (2015). Kozier and Erb's fundamentals of nursing. Melbourne: Pearson.

Bowman, C. W. (1997). Lifelong learning for professional engineers. Engineering Issues, 6, 1-2.

Braithwaite, D. O., Schrodt, P., \& Carr, K. (2015). Meta-theory and theory in interpersonal communication research. In D. O. Braithwaite \& P. Schrodt (Eds.). Engaging theories in interpersonal communication: Multiple perspectives (pp. 1-20). California: Sage Publication, Inc.

Brandt, C., \& Dimmitt, N. (2015). Transfer of learning in the development of peer tutor competence. Learning and Teaching in Higher Education: Gulf Perspectives, 12(2).

Burgoon, J. K., Guerrero, L. K., \& Floyd, K. (2016). Nonverbal communication. New York, NY: Routledge.

Burnett, P. C. (1999). Children's self-talk and academic self-concepts. Educational Psychology in Practice, 15(3), 195-199.

Canter, L. (2006). Lee Canter's classroom management for academic success. Bloomington, IN: Solution Tree Press.

Commission of the European Communities. (2005). Proposal for a recommendation of the European Parliament and of the Councils on key competences for lifelong learning. Brussels Retrieved from http://www.europarl.europa.eu/meetdocs/2004_2009/documents/comcom_com(2005) 0548_/com_com(2005)0548_en.pdf

Coşkun, Y. D., \& Demirel, M. (2012). Lifelong learning tendencies of university students. Hacettepe University Journal of Education, 42, 108-120.

Crowder, J. A., Carbone, J. N., \& Demijohn, R. (2016). Multidisciplinary systems engineering: Architecting the design process. London: Springer.

Davis, H. A. (2001). The quality and impact of relationships between elementary school students and teachers. Contemporary Educational Psychology, 26, 431-453.

Demirel, M. (2009). Lifelong learning and schools in the twenty-first century. Procedia Social and Behavioral Sciences, 1, 1709-1716. 
Deveci, T., \& Ayish, N. (2018). Personal responsibility and interpersonal communication skills of freshman students in a project-based course. International Journal of Social Sciences and Education Research, 4(1), 1-17.

Deveci, T., \& Ayish, N. (2017). Engineering students' well-being experiences: A freshman year experience program. Transformative Dialogues: Teaching \& Learning Journal, 9(3), 1-20.

Deveci. T. (2014). Lifelong learning orientations of freshman engineering students and faculty members, Journal of Higher Education, 4(1), 14-22.

Deveci, T. (2013). Promoting lifelong learning, The Asian EFL Journal Professional Teaching Articles, 7, 4-19.

Devos, N. J. (2016). Peer interactions in new content and language integrated settings. London and New York: Springer.

Dewey, J. (1933). How we think: A restatement of the relation of reflective thinking and the educational process. New York: D.C Heath.

DiDomenico, C. F. (2010). Lifelong learning, engineering and the community college. Paper presented at Conference for Industry and Education Collaboration, Palm Springs, California. Retrieved from http://www.indiana.edu/ ciec/Proceedings_2010/ Papers/ ETD/ETD443_ DiDomenico.pdf

Dukmak, S. (2010). Classroom interaction in regular and special education middle primary classrooms in the United Arab Emirates. British Journal of Special Education, 37(1), 39-48.

Duck, S., \& McMahan D. T. (2017). Communication in everyday life ( $2^{\text {nd }}$ ed). Singapore: Sage Publications, Inc.

Duman, A. (2007). Yetişkinler eğitimi (2. bs) [Adult education. (2 ${ }^{\text {nd }}$ ed.)]. Ankara: Utopya.

Dunne, E. (1999). The learning society: International perspectives on core skills in higher education. London and New York: Routledge.

Edwards, R. (2001). Meeting individual learner needs: Power, subject, subjection. In C. Paechter, M. Preedy, D. Scott \& J. Soler (Eds.). Knowledge, power and learning (pp. 37-46). London: Open University.

Edwards, G., \& Stimpson, P. (2003). Environmental citizenship education. In M. Williams \& G. Humphrys (Eds). Citizenship education and lifelong learning: Power and place (pp. 89-99). New York, NY: Nova Science Publisher, Inc.

Erdoğan, D. G., \& Arsal, Z. (2016). The development of lifelong learning trends scale. Sakarya University Journal of Education, 6(1), 114-122.

Furrer, C. J., Skinner, E. A., \& Pitzer, J. R. (2014). The influence of teacher and peer relationships on students' classroom engagement and everyday motivational resilience. National Society for the Study of Education, 113(1), 101-123

Gilton, D. L (2012). Lifelong learning in public libraries: Principles, programs, and people. Plymouth: The Scarecrow Press, Inc.

Guo-Dong, X. (1994). Lifelong Education in China: New policies and activities. International Review of Education, 40(3/5), 271-281.

Hargie, O. (2016). Skilled interpersonal communication: Research, theory and practice (Sixth Edition). London and New York: Routledge.

Head, A. J. (2016). Staying smart: How today's graduates continue to learn once they complete college. Seattle: University of Washington, Project Information Literacy Research Report. Accessed through http://projectinfolit.org/images/pdfs/2016_lifelonglearning_fullreport.pdf

Jarvinen, A. (1998). Consultative and learning approaches in the context of organizational process and innovations. In C. Griffin, J. Holford, \& P. Jarvis (Eds). International perspectives on lifelong learning (pp. 291-302). London and New York: Routledge.

Jarvis, P. (2009). Lifelong learning: A social ambiguity. In P. Jarvis (Ed.). The Routledge international handbook of lifelong learning (pp. 9-18). London and New York: Routledge. 
Johnson, D. W. (1978). The importance of interpersonal skills. In S. L. Tubbs \& R. M. Carter (Eds.) Shared experiences in human communication (pp. 21- 49). New Jersey, NJ: Hayden Book Company, Inc.

Hurst, B., Wallace, R., \& Nixon, S. B. (2013). The impact of social interaction on student learning. Reading Horizons, 52(4), 375-398.

Kaiser, H. F. (1974). An index of factorial simplicity. Psychometrika, 39, 31-36.

Kember, D., \& Leung, D. Y. P. (2005). The influence of active learning experiences on the development of graduate capabilities. Studies in Higher Education, 30(2), 155-170.

Korkut-Owen, F., \& Bugay, A. (2014). Developing a communication skills scale: Validity and reliability studies. Mersin University Journal of the Faculty of Education, 10(2), 51-64.

Kumar, A. (2012). Philosophical background of adult and lifelong learning. Retrieved from http://www.unesco.org/education/aladin/paldin/pdf/course01/unit_03.pdf

Lewis, R. B. (1981). The philosophical roots of lifelong learning. Abstract retrieved from ERIC database, (ED213356).

Lewittes, H. (2009). A critical thinking rubric as the basis of assessment and curriculum. In C. S. Schreiner (Ed). Handbook of research on assessment technologies, methods, and applications in higher education (pp. 22-46). Hershey, PA: IGI Global.

Longworth, N., \& Davies, W. K. (2013). Lifelong learning: New vision, ne implications, new roles for people, organizations, nations and communities in the $21^{\text {st }}$ century. London and New York: Routledge.

Matheson, D., \& Matheson, C. (1996). Lifelong Learning and lifelong education: A critique. Research in Post-Compulsory Education, 1(2), 219-236.

Martin, A. J., \& Collie, R. J. (2016). The role of teacher-student relationships in unlocking students' academic potential: Exploring motivation, engagement, resilience, adaptability, goals, and instruction. In K. R. Wentzel \& G. B. Ramani (Eds.) Handbook of social influences in school contexts: Social engagement, motivation and cognitive outcomes (pp. 158-177). New York and London: Routledge.

OECD. (2004). Internalisation and trade in higher education: Opportunities and challenges. Paris.

Özturk, F., Deveci, T., Günister, E., \& Simmons, R. J. (2015). Innovative instructional strategies for teaching materials science in engineering. In H. L. Lim (Ed.) Handbook of research on recent developments in materials science and corrosion engineering education (pp. 100-117). PA: IGI Global.

Patil, A., \& Eijkman, H. (2012). Megatrends in engineering and technology education: A call for the communicative imagination. In A. Patil, H. Eijkman \& E. Bhattacharyya (Eds.). New media communication skills for engineers and IT professionals: Trans-national and trans-cultural demands (pp. 1-8). Hershey, PA: Information Science Reference.

Riemer, M. J. (2007). Communication skills for the 21st century engineer. Global Journal of Engineering Education, 11(1), 89-100.

Roncaglia, I. (2016). A practitioner's perspective of multidisciplinary teams: analysis of potential barriers and key factors for success, Psychological Thought, 9(1), 15-23.

Rovai, A. P. (2003). In search of higher persistence rates in distance education online programs. Internet and Higher Education, 6, 1-16.

Reilly, S. (2008). The submissive goal-setting journal. Fayetteville, NC: DV8 Publishing.

Sarvaiya, M. (2013). Human communication. Mumbai: Lulu.

Sayllan, F. (2015). Some critical reflections on lifelong learning policy in Turkey. Journal for Critical Education Policy Studies, 12(3), 156-170.

Skinner, K. L., Hyde, S. J., McPherson, K. B. A., \& Simpson, M. D. (2016). Improving students' interpersonal skills through experiential small group learning. Journal of Learning Design, 9(1), 21-36. 
Solomon, D., \& Theiss, J. (2013). Interpersonal communication: Putting theory into practice. London and New York: Routledge.

Tenopir, C., \& King, D. W. (2004). Communication pattern of engineers. New York, NY: Wiley Interscience.

Titmus, C. (1989). Lifelong education for adults: An international handbook. Oxford: Pergamon Press.

Turner, J. H. (1988). A theory of social interaction. Stanford: Stanford University Press.

Uzunboylu, H., \& Hürsen, Ç. (2011). Lifelong learning competence scale (LLLCS): The study of validity of reliability. Hacettepe University Journal of Education, 41, 449-460.

Weeden, P., \& Winter, J. (1999). The learn project: Learners' expectations of assessment for learning nationally. Report for the Qualifications and Curriculum Authority, Bristol: University of Bristol, Graduate School of Education.

Williams. S. (n.d.). Listening effectively. Retrieved from http://www.wright.edu/ scott.williams/ LeaderLetter/listening.htm

Yong, A. G., \& Pearce, S. (2013). A beginner's guide to factor analysis: Focusing on exploratory factor analysis. Tutorials in Quantitative Methods for Psychology, 9(2), 79-94.

\section{Appendix}

The scale of interpersonal communication predispositions for lifelong learning scale (SICP-LLL)

Factors and Factor Load Values

\begin{tabular}{|c|c|c|c|c|c|}
\hline $\begin{array}{c}\text { Item } \\
\text { no }\end{array}$ & Items & $\begin{array}{c}\text { Factor } \\
1\end{array}$ & $\begin{array}{l}\text { Factor } \\
\quad 2\end{array}$ & $\begin{array}{l}\text { Factor } \\
3\end{array}$ & $\begin{array}{c}\text { Factor } \\
4\end{array}$ \\
\hline \multicolumn{6}{|c|}{ Learning reciprocity } \\
\hline 1 & $\begin{array}{l}\text { It is important for me to have good } \\
\text { relationships with people who can help me } \\
\text { learn. }\end{array}$ & .685 & & & \\
\hline 2 & $\begin{array}{l}\text { I am open to sharing my knowledge and skills } \\
\text { with peers who may benefit from them. }\end{array}$ & .628 & & & \\
\hline 3 & $\begin{array}{l}\text { Conversations with friends can help me look at } \\
\text { things from different perspectives. }\end{array}$ & .597 & & & \\
\hline 4 & $\begin{array}{l}\text { I like to communicate with others because I am } \\
\text { interested in what they might have to teach me. }\end{array}$ & .583 & & & \\
\hline 5 & $\begin{array}{l}\text { I can change my communication style } \\
\text { according to other people's preferences. }\end{array}$ & .502 & & & \\
\hline 6 & $\begin{array}{l}\text { I'd like to help people with learning needs like } \\
\text { mine. }\end{array}$ & .452 & & & \\
\hline 7 & $\begin{array}{l}\text { I am careful with my actions because they may } \\
\text { affect my friends' learning. }\end{array}$ & .450 & & & \\
\hline 8 & $\begin{array}{l}\text { I can make my friends feel comfortable when } \\
\text { we study together. }\end{array}$ & .443 & & & \\
\hline 9 & I inspire my friends to learn. & .420 & & & \\
\hline 10 & $\begin{array}{l}\text { I seek advice from others when I need to make } \\
\text { a difficult decision about learning. }\end{array}$ & .354 & & & \\
\hline 11 & $\begin{array}{l}\text { I enjoy talking to other people about learning } \\
\text { and development. }\end{array}$ & .343 & & & \\
\hline
\end{tabular}




\begin{tabular}{|c|c|c|c|c|c|}
\hline 12 & $\begin{array}{l}\text { I can adjust my way of talking to others } \\
\text { according to how much they know about the } \\
\text { topic of our conversation. }\end{array}$ & .327 & & & \\
\hline \multicolumn{6}{|c|}{ Perseverance } \\
\hline 13 & $\begin{array}{l}\text { I will lose my motivation if I have difficulty } \\
\text { using my new knowledge when working with } \\
\text { other people. }\end{array}$ & & .743 & & \\
\hline 14 & $\begin{array}{l}\text { When working together, my friends' learning } \\
\text { difficulties will easily affect my motivation to } \\
\text { study. }\end{array}$ & & .699 & & \\
\hline 15 & $\begin{array}{l}\text { If I had a problem with a friend, I would never } \\
\text { study with him/her again. }\end{array}$ & & .644 & & \\
\hline 16 & $\begin{array}{l}\text { I feel a lot of stress when I need to write a } \\
\text { formal email to my instructors, so I prefer to } \\
\text { avoid it as long as I can. }\end{array}$ & & .619 & & \\
\hline 17 & $\begin{array}{l}\text { I have difficulty in cooperating with others } \\
\text { when I need to learn new things. }\end{array}$ & & .578 & & \\
\hline 18 & $\begin{array}{l}\text { I find it stressful when others comment on my } \\
\text { learning. }\end{array}$ & & .490 & & \\
\hline 19 & $\begin{array}{l}\text { I don't give up easily in the face of a learning } \\
\text { problem caused by other people. }\end{array}$ & & .302 & & \\
\hline \multicolumn{6}{|c|}{ Engagement with instructors } \\
\hline 20 & $\begin{array}{l}\text { Asking my instructors questions is not a } \\
\text { problem for me when I don't understand } \\
\text { something. }\end{array}$ & & & .738 & \\
\hline 21 & $\begin{array}{l}\text { I listen to my instructors' advice about how to } \\
\text { remain a successful learner after graduation. }\end{array}$ & & & .691 & \\
\hline 22 & $\begin{array}{l}\text { I go to my instructor's office to talk about } \\
\text { different ways I can improve myself. }\end{array}$ & & & .667 & \\
\hline 23 & My instructors inspire me to learn. & & & .587 & \\
\hline 24 & $\begin{array}{l}\text { I value my instructors' use of pair and group } \\
\text { work activities in the classroom. }\end{array}$ & & & .557 & \\
\hline \multicolumn{6}{|c|}{ Motivation } \\
\hline 25 & $\begin{array}{l}\text { I enjoy doing collaborative work with other } \\
\text { students. }\end{array}$ & & & & .693 \\
\hline 26 & $\begin{array}{l}\text { I try to study with others to develop myself } \\
\text { without any pressure from others. }\end{array}$ & & & & .684 \\
\hline 27 & I like to find out about how my friends learn. & & & & .628 \\
\hline 28 & $\begin{array}{l}\text { When setting learning goals for myself, I like } \\
\text { to have others' contribution. }\end{array}$ & & & & .592 \\
\hline 29 & $\begin{array}{l}\text { I prefer to spend my time with my friends for } \\
\text { fun, not for learning new things. }\end{array}$ & & & & .587 \\
\hline 30 & $\begin{array}{l}\text { I do not like to speak with other people about } \\
\text { my education ambitions. }\end{array}$ & & & & .497 \\
\hline
\end{tabular}

